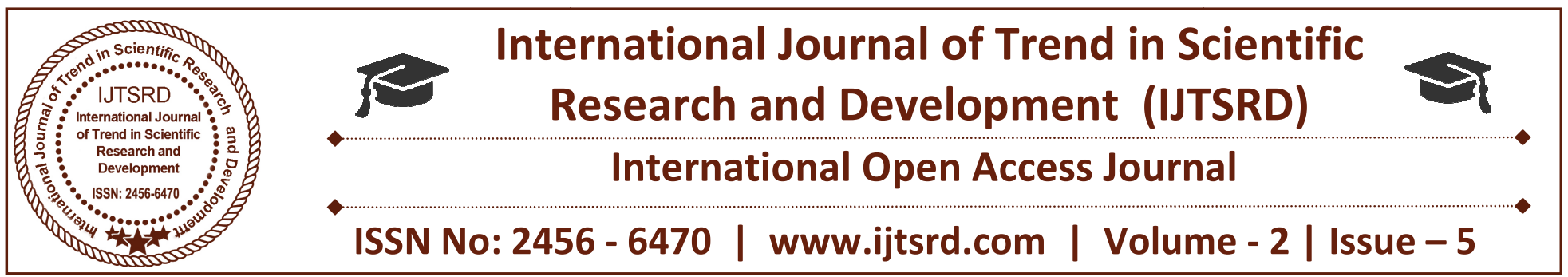

\title{
Intellectual Property Right for Making in India: A Legal Right
}

\author{
Kshirod Kumar Moharana ${ }^{1}$, Dr. Laxmikanta Das ${ }^{2}$ \\ ${ }^{1}$ Research Scholar, ${ }^{2}$ Assistant Professor, \\ ${ }^{1}$ Lecture in Law, Biraja Law College, Jajpur, Odisha, India \\ ${ }^{2}$ L R Law College, Sambalpur University, Sambalpur, Odisha, India
}

\section{ABSTRACT}

Intellectual Property Right is a legal concept which is creations of human intellect under intellectual property law; owners are granted certain exclusive rights to a variety of intangible assets, such as musical, literary and artistic works; discoveries and inventions of words, phrases, symbols, designs etc. Common types of intellectual property rights are copyright, trademarks, patents, industrial, trade dress and some jurisdictions secrets. So it is a most controversial term referring to a number of distinct types of expression. IPR now becomes most contentious issues in this global world. The major issues relating IPR not only dominate trade among nation in agricultural, pharmaceutical, geographical induction, sustainable development of patent right, copy right, trademark, performing Art but it also challenges various issues for reliance of the legal right and obligation of the indigenous invention, industrial product, agricultural product, geographical induction. There are so many organization for the protection of the intellectual property rights such as TRIPS agreement, WTO, GATT, WIPO, special jurisdiction etc are working under the national and international jurisdiction for protection and solving issues of intellectual property rights. Now an intellectual property right in India becomes challengeable for protection of new invention and for the making of India into a new trend. Intellectual property Right plays an important role in India by increasing broad range of areas, ranging from the Internet to health care to nearly all aspects of science and technology, literature and the arts. The role of intellectual property in these areas - many of them still emerging - often requires significant new research and study. The emergence of new technologies, in particular, rapid breakthroughs in biotechnology, the adoption of new business processes and methods, the spread of new software threaten entire industries. These new technologies, some of which are controversial, have either made IPR more vulnerable or rendered the existing IPR regime obsolete. This paper emphasizes the legal obligation for protection of IPR to make the India into a protective measure and current emerging trends in intellectual property regimes in the field of agriculture and pharmaceuticals, geographical induction and protection of traditional knowledge for making in India.

Keywords- Pharmaceutical, Geographical Induction, Patent, Trademark, Copyright

\section{INTRODUCTION}

Intellectual Property Right is a legal concept which is creations of human intellect under intellectual property law; owners are granted certain exclusive rights to a variety of intangible assets, such as musical, literary and artistic works; discoveries and inventions of words, phrases, symbols, designs etc. Common types of intellectual property rights are copyright, trademarks, patents, industrial, trade dress and some jurisdictions secrets. So it is a most controversial term referring to a number of distinct types of expression. IPR now becomes most contentious issues in this global world. The major issues relating IPR not only dominate trade among nation in agricultural, pharmaceutical, geographical induction, sustainable development of patent right, copy right, trademark, performing Art but it also challenges various issues for reliance of the legal 
right and obligation of the indigenous invention, industrial product, agricultural product, geographical induction.

The emergence of new technologies, in particular, rapid breakthroughs in biotechnology, the adoption of new business processes and methods, the spread of new software, such as Napster's file-sharing program threaten entire industries. These new technologies, some of which are controversial, have either made IPR more vulnerable or rendered the existing IPR regime obsolete. The globalization of technology and human resources with the rapid increases in foreign direct investment and improvement in technology, the flow of critical technologies and skills has expanded and accelerated, both within the developed world and between the developed and developing economies ${ }^{1}$. The movement of capital and technology has, ironically, made IPR both more valuable and vulnerable at the same time. ${ }^{2}$

World Health Organization (WHO) estimatation on all pharmaceuticals sold worldwide becomes counterfeit. In some developing countries, fake medicine, sales of counterfeit vehicle parts, raising serious safety and liability issues for legitimate automobile and auto parts manufacturers, in addition to damaging their brands. Besides counterfeiting, copyrights infringement and the use of pirated materials pose another challenge in the protection of IPR. According to the Office of the United States Trade Representative (OUSTR), the loss of revenue from the use of pirated copyright materials, such as motion pictures, records and music, business software, entertainment software, and books, In the Special 301 list published by the OUSTR in $2005^{3}$, rampant use of pirated copyright materials. Now becomes major issues and challenges to the India and other developing and developed countries. ${ }^{4}$

\section{LEGAL OBLIGATION:-}

The current emerging trends in intellectual property basically depends on the globalization of new technology and human resources, the rapid increases

\footnotetext{
${ }^{1}$ Intellectual Property Rights:A Survey of the Major Issues A Report for the Asia Business Council By Minxin Pei, Carnegie Endowment for International Peace September 2005

2 Availableat-http://www.asiabusinesscouncil.org/docs/

${ }^{3}$ Myron Brilliant, Vice President, East Asia, U.S. Chamber of Commerce, "Testimony before the House

Judicial Subcommittee on the Courts, the Internet and

Intellectual Property," May 17, 2005;

${ }^{4}$ ibid
}

in foreign direct investment and improvement in technology flows a critical technologies and skills. For this reason new technology accelerate the economics in developing country. The movement of capital and technology has ironically made IPR more valuable and vulnerable. ${ }^{5}$

The emergence of new technologies such as rapid breakthroughs in biotechnology, agricultural product, and geographical induction adopted a new business processes and methods, and the spread of new software, which becomes controversial such as the patenting of genetic materials, have either made IPR more vulnerable or rendered the existing IPR regime obsolete. The growing role of emerging markets in the global economy coincides with these countries' weak ability to protect IPR. At a fundamental level, the incentives of developing countries conflict with those of developed countries. IPR has gained commercial and political salience in recent years because the stakes involved are huge and growing. IPR violations cause job and revenue losses in rich countries.

More important issues are counterfeiting increases public safety and health risks. The World Health Organization (WHO) estimates that 10 percent of all pharmaceuticals sold worldwide are counterfeit. In some developing countries, fake medicine accounts for as high as 60 percent of the drugs sold. Worldwide, sales of counterfeit vehicle parts amount to $\$ 12$ billion each year, raising serious safety and liability issues for legitimate automobile and auto parts manufacturers, in addition to damaging their brands. ${ }^{6}$

Besides these, copyrights infringement and the use of pirated materials pose another challenge in the protection of IPR. According to the Office of the United States Trade Representative ${ }^{7}$ (OUSTR), the loss of revenue from the use of pirated copyright materials, such as motion pictures, records and music, business software, entertainment software, and books amounts to $\$ 12$ billion a year for American firms. ${ }^{8}$ In terms of copyright materials being pirated, the largest

\footnotetext{
5 Available

athttp://www.asiabusinesscouncil.org/doc/intellectualpropertyrig hts.pdf

6 Available at-

http://www.worldcourier.com/ensights.events.events/market.ingi

hts/detail/searchingglobal-pharmaceatical-supply-chain.

${ }^{7}$ ibid

8 Available at-http://demony.com/1790879.html
} 
category was business software $(\$ 5.69$ billion, or almost half of the lost revenue); it was followed by records and music ( $\$ 2.44$ billion). Losses from pirated entertainment software ( $\$ 1.74$ billion) and motion pictures ( $\$ 1.64$ billion) were about the same ${ }^{9}$. The rapid spread of counterfeiting and pirated copyright materials is caused by several factors, among them. ${ }^{10}$

Available low-cost technology enables counterfeiters to produce high-quality goods for the gray markets. ${ }^{11}$ For example, a "rapid prototype" machine can take a three-dimensional digital scan of a plastic or wooden toy and reproduce a prototype within hours. ${ }^{12}$ Sevendisk DVD burning machines costing only $\$ 650$ each, compared with DVD pressing equipment that costs $\$ 1$ million each, allow smaller pirating operations, which are more difficult to root out. Consumers attach little moral stigma to purchasing counterfeits or pirated copyright materials. According to a survey of 500 Japanese school teachers, 20 percent of them have bought counterfeits. ${ }^{13}$

The issue regarding any direct relationship between the creation and exploitation of intellectual property and trade as depicted under TRIPS was debated even at the time of negotiations for the GATT. Even after over 15 years of signing the GATT in 1994 and the establishment of WTO in January 1995, the issue is still being discussed. There are those who still believe that there is not even any empirical evidence that matters related to IPR protection indeed influence and increase global trade. Some even opine that the IPR protection system in fact stifles free trade in view of the monopolistic character of the system, however limited it is with respect to time frame. While all the member countries of WTO have enacted national legislations to implement a TRIPS compliant patent system, there are some real or perceived distortions and deficiencies in the patent systems practiced by some of the member countries ${ }^{14}$

\footnotetext{
${ }^{9}$ Intellectual Property Rights: A Survey of the Major Issues ,A Report for the Asia Business Council By Minxin Pei, Carnegie Endowment for International Peace September 2005

${ }^{10}$ Available at- http://www.camcode.com/asset-tags/cash-m

${ }^{11}$ Available at- http://www.asiabusinesscouncil.org/docs/

${ }^{12}$ Available at-http//responsibility-rri.eu/wpcontent/uploads/2004/RESPONSIBILITY-024-theoriticallandscape_final-EC-public-pdf.

13 ibid

${ }^{14}$ M D Nair $\dagger$, TRIPS, WTO and IPR: Prevailing Issues and Emerging Trends ,A-11, Sagarica, 15, 3rd Seaward Road, Valmiki Nagar, Thiruvanmiyur, Chennai 600041 ,12 April 2010
}

\section{PROTECTION OF TRADITIONAL KNOWLEDGE:-}

Patents provide inventors of new products and technologies the legal right to exclude rivals from making, selling, and distributing those inventions. ${ }^{15}$ Trademarks provide their owners the right to prevent rivals from using identical or confusingly similar identifying marks and trade names on their goods. ${ }^{16}$ Article- 6 of TRIPS states that: ${ }^{17}$ "For the purposes of dispute settlement under this Agreement, subject to the provisions of Articles 3 and 4, nothing in this Agreement shall be used to address the issue of the exhaustion of intellectual property rights." 18

This Article implies that, no violation or limitation of a TRIPS obligation beyond national treatment (Article-3) and most favored nation (Article-4) may be invoked to challenge the treatment of parallel imports. ${ }^{19}$ Overall, it seems that Article-6 preserves the territorial prerogative to regulate parallel trade. This flexibility was important in gaining the acceptance of TRIPS by many developing countries. ${ }^{20}$ Undoubtedly many negotiators from developing countries considered PI to be an effective antidote to concerns about the potential price impacts of pharmaceutical patents required by the agreement. ${ }^{21}$ Thus, original manufacturers retain complete authority to distribute goods and services themselves or through dealers, including the right to exclude PI through border controls. In contrast, countries permitting PI are not territorially segmented and do not recognize any right to exclude imports of goods in circulation abroad. $^{22}$

Two major issues are, opponents of PI often claim that permitting them would support consumer deception and trade in counterfeit goods and pirated goods. Consumer deception would occur if lowerquality parallel imports were marketed as legitimate versions of higher-quality products. Counterfeiting and piracy are trade in unauthorized versions of

\footnotetext{
15 Available at-http://www.researchgate.net/publication/

${ }^{16}$ Available at-

http://.wipo.int/export/site/www/about_ip/en/studies/pdf/sa_mar ks_pi.pdf.

${ }^{17}$ ibid

${ }^{18}$ ibid

${ }^{19}$ Available at- http://www.researchgate.net/publication/

${ }^{20}$ ibid

${ }^{21}$ Keith E. Maskus Professor of Economics University of Colorado at Boulder UCB 256, Boulder CO 80309-0256 USA

Maskus@colorado.edu

${ }^{22}$ ibid
} 
products, which is a different concept than parallel imports. In either case, customs authorities are empowered to act against such trade without restricting genuine PI. Nonetheless, as a practical matter there could be some difficulties with deception and product quality, raising the costs of effective monitoring at the border. ${ }^{23}$

Second, a ban on PI per se does not extend to preventing imports of generic drugs or imitative drugs that may be legitimately on the market in another country because the original products are not patented there. However, if domestic sale of such drugs would violate patents owned in the importing market, they may be excluded for that reason. Exhaustion policies vary widely in the area of pharmaceuticals. ${ }^{24}$

An important exception is that if products are placed on the market under a compulsory license, they may not be parallel imported. Within its territory the United States employs the first-sale doctrine, under which rights are exhausted when purchased outside the vertical distribution chain. Thus, companies cannot prevent customers from re-selling goods anywhere within the country.

There are now a number of E-commerce "pharmacies" (distributors) offering prescription, trademarked drugs to consumers at prices below retail. ${ }^{26}$ Under its trademark law the United States could be open to PI subject to its "common-control exception". 27 This rule allows trademark owners to bar PI except when both the foreign and U.S. trademarks are owned by the same entity or when the foreign and U.S. trademark owners are in a parent-subsidiary relationship. ${ }^{28}$ Furthermore, for a trademark owner to block PI it must demonstrate that the imported goods are not identical in quality to the original products and could cause confusion among consumers. ${ }^{29}$ These principles would suggest that PI in pharmaceuticals are permissible for they are certainly identical to original products. $^{30}$

Developing countries vary widely in their restraints on PI of pharmaceuticals. Some nations disallow PI

\footnotetext{
23 ibid

24 ibid

${ }^{25}$ ibid

${ }^{26}$ Available at-http://www.wipo.int/export/sites/www/abo

27 ibid

${ }^{28}$ K Mart Corporation v Cartier, 486 US 281 (1987).

${ }^{29}$ ibid

${ }^{30}$ ibid
}

because their patent laws provide a strict right of importation to authorized licensees; these laws are common in countries with British or French colonial legacies. Moreover, several developing nations have laws permitting only one national distributor for products imported under trademark, effectively banning parallel imports. ${ }^{31}$

In agriculture, Plant breeders, biotechnology scientists and the firms that own biotech inventions try to charge enough royalties for use of their inventions or prevent people or firms from copying their inventions so that they can sell enough of their invention at a high enough price to profit from their investment in research and development. ${ }^{32}$ They control the use of their inventions by using legal means such as patents, plant breeders' rights, and trademarks. They also do this by keeping their inventions or key parts of their inventions secret which in some countries are protected by trade secrecy law. They also protect their inventions by biological means such as putting new characteristics into hybrid cultivars or including other technical means to prevent copying. ${ }^{33}$ In a few cases countries give one company a monopoly on the production and sales of a particular commodity. ${ }^{34}$

Laws to protect new plant varieties and biotech inventions spread rapidly in developing countries in the late 1990s. Their spread was accelerated by the intellectual property rights component of the World Trade Organization agreement which required signatories to put in place some type of sui generis system of plant variety protection and patent protection for biotechnology inventions by 2000. A number of countries still exclude novel plants and animals from patent coverage although many of them do allow patenting of novel microbes as it required by $\mathrm{WTO}^{35}$.

As part of the GATT Agreement which led to the formation of WTO in 1995, all the 153 members of

\footnotetext{
${ }^{31}$ ibid

${ }^{32}$ Available at-http://ageconsearch.umn.edu/bitstream/22

33 Available at-https://en.wikipedia.org/wiki/Monopoly

${ }^{34}$ Available at-

http://citeseex.ist.pcu.edu/viewdoc/download?dui-10-1152159868rep $=$ rep 18 type $=$ pdf

35 The Importance of Intellectual Property Rights in the International Spread of Private Sector Agricultural

Biotechnology, Carl E. Pray,_Ann Courtmanche, and_Ramu Govindasamy Department of Agricultural, Food and Resource Economics Rutgers, the State University of New Jersey 55 Dudley Road, New Brunswick, NJ 08904 U.S.A.
} 
WTO were/are to implement the terms of the Agreement on Trade-Related Intellectual Property Rights (TRIPS) on or before the dates prescribed in the Agreement for each of the members. These dates vary according to the developmental status of the members and their classification as developed, developing and least developed. While all the member countries have been working actively during the last decade to meet these deadlines, many issues which impinge on the proper implementation of all the provisions under TRIPS by the members are still unresolved. As we enter the second decade of the new millennium, it is prudent to take stock of the prevailing issues and the emerging trends in the implementation of the TRIPS and related agreements by the members of WTO.

During the last two years, 2008 and 2009, the world has seen one of the worst economic downturns in its history. Two of the major indices for assessing state of the economy are those related to GDP growth and global trade. During 2009, World GDP declined by $2.3 \%$ while the Indian GDP, unlike that of many developed countries grew by $5.4 \%$. Global exports came down by $12.2 \%$ and imports by $12.9 \%$ while exports from India declined by only $6 \%$ and imports Declined by $4.4 \%$. According to the WTO's press release of 26 March 2010, the year 2009 saw decline of $12.2 \%$ in global trade by volume, the largest since 1965. The major losers have been the US-13.9\%, the European Union-14.8\% and Japan-24.9\%. The Asian countries lost trade to the tune of $11.1 \%$, the oil rich Middle East countries, $4.9 \%$ and African nations, $5.6 \%$. Reduction in consumer demand, reduced investments particularly in the manufacturing sector, unemployment, non availability of finance required for growth oriented projects are the reasons attributed to such a dismal economic scene.

Economists believe that the worst is over and that 2010 will see an increase in world trade by around $+9.5 \%$ and unless fresh protectionist measures from the major trading countries are brought in through unilateral action by the bigger economies, return to pre- 2008 levels of growth are being forecast given consistent growth for at least two years. ${ }^{36}$

The issue regarding any direct relationship between the creation and exploitation of intellectual property and trade as depicted under TRIPS was debated even at the time of negotiations for the GATT. ${ }^{37}$ Even after over 15 years of signing the GATT in 1994 and the establishment of WTO in January 1995, the issue is still being discussed. Some even opine that the IPR protection system in fact stifles free trade in view of the monopolistic character of the system, however limited it is with respect to time frame. While all the member countries of WTO have enacted national legislations to implement a TRIPS compliant patent system, there are some real or perceived distortions and deficiencies in the patent systems practiced by some of the member countries. And these are not restricted to developing countries. Protectionist measures including provisions under the guise of safeguard measures such as under the 301 and Super 301 laws in the US are still operative. In addition, the US continues the practice of 'first to invent' against 'first to file' principle mandated under TRIPS for establishing priority. ${ }^{38}$

Apart from monitoring the progress in the implementation of the provisions and dictates of the TRIPS Agreement in all member countries, the WTO is faced with the problem of finalizing the Doha Round mooted in 2001 at the Inter Ministerial Conference at Doha. As against the eight years (1986994) for finalizing the Uruguay Round, already nine years have passed since the initiation of the Doha Round. While some progress has been made since 2008, the gaps faced by the multinational corporations account for two thirds of world trade and industrialized countries file and receive over $95 \%$ of all patents. Even in developing countries, which have opened the doors for patenting of inventions under a harmonized system dictated by TRIPS, $80 \%$ of the patentees are from the developed countries.

In spite of the operational complexities, one of the important instruments under the WTO, the Dispute Settlement Board has functioned well since its inception. To date there have been 400 disputes (both bilateral and multilateral) referred to the Board of which half have been settled through negotiations without going into litigations. 169 have been subject of the panel and were appealed, before the appellate body, 17 are currently in adjudication and the rest under active consultations.

\footnotetext{
36 Available-Journal of Intellectual Property Rights Vol15, May 2010, pp 235-237 .TRIPS, WTO and IPR: Prevailing Issues and Emerging Trends
}

\footnotetext{
37 Available at-http://nopr.niscair.res.in/bit stream/123

${ }^{38}$ Supra note
} 
For all practical purposes, the Indian Patents Act 2005 is operating as per the provisions of TRIPS with minor changes in interpretation of certain provisions to meet the Indian requirements. Three areas where India has included TRIPS plus provisions are Section $3(d)^{39}$ on patentability, obligatory disclosure of source of natural resources and provisions for pre-grant Opposition.

There is no evidence that India has defaulted on any of her obligations under the TRIPS Agreement. India has provided facilities for filing applications under PCT and has facilities for depositing patented microorganisms in a depository as required under the Budapest Treaty. There has been a dramatic increase in filing of applications as well as grant of patents.

The number of applications for all inventions in all sectors was 35,218 in 2007-2008, an all-time high, of which pharmaceuticals accounted only for 4267 . US applicants topped the list with 8606 applications followed by Germany and Japan. Number of patents in force was 29,688 of which drugs sector had only 1469. In 2007-2008, 11,751 patent applications were examined and number of patents granted that year. Thus while the numbers are still far below those of Western countries or even China, the sudden spurt indicates that patenting has been accepted as an important instrument for encouraging investments in research. $^{40}$

The coming into force of Indian Patents Act (IPA) 2005 has resulted in a number of litigations. Expectedly most of them were related to Section 3(d) of IPA- 2005 which prohibited patenting of so called trivial inventions. The most conspicuous ones in recent times have been the patent applications on Glivec by Novartis, Tarceva of Roche and the CIPLA's generic Sorafenib Tosylate of Bayers drug.

Other issues which beg for resolution through legal or administrative procedures are connected with provisions for protection of data (data exclusivity), anti-competition practices, parallel imports, protection of traditional knowledge through appropriate protection systems, simplification of compulsory licenses, geographical indication to extend rights

\footnotetext{
${ }^{39}$ The TRIPS Agreement, which came into effect on 1 January 1995 , is to date the most comprehensive multilateral agreement on intellectual property.

${ }^{40}$ M D Nair $\dagger$,A-11, Sagarica, 15, 3rd Seaward Road, Valmiki Nagar, Thiruvanmiyur, Chennai 600041 ,12 April 2010
}

beyond wines and spirits, implementation of the provisions under the Biodiversity Act ( not a TRIPS issue), exploitation of publically funded research through Bolar like provisions and handling of pregrant and post-grant opposition cases expeditiously. Development of adequate infrastructure, skilled human resources and spreading awareness of the need for establishing a reward system for intellectual property creation through IPR protection are other areas of high priority.

A geographical indication (GI) is a name or sign used on certain products which corresponds to a specific geographical location or origin (e.g. a town, region, or country). India, as a member of the World Trade Organization (WTO), enacted the Geographical Indications of Goods (Registration and Protection) Act, 1999 has come into force with effect from 15 September 2003. GIs have been defined under Article $22(1)^{41}$ of the WTO Agreement on Trade-Related Aspects of Intellectual Property Rights(TRIPS) Agreement as: "Indications which identify a good as originating in the territory of a member, or a region or a locality in that territory, where a given quality, reputation or characteristic of the good is essentially attributable to its geographic origin.

The GI tag ensures that none other than those registered as authorized users (or at least those residing inside the geographic territory) are allowed to use the popular product name. Darjeeling tea became the first tagged product in India, in 2004-05, since then by September 2010, 184 had been added to the list. A geographical indication (GI) is a name or sign used on certain products which corresponds to a specific geographical location or origin (eg. a town, region, or country). The use of a GI may act as a certification that the product possesses certain qualities, or enjoys a certain reputation, essentially attributable to their geographical origin.

The protection is granted to GI through registration. The registration of GI is not granted to any individual. It is a national property, it is granted to associations of persons or producers or an organization or authority representing the interest of the producers of goods. After a GI is first registered in the name of association of persons, separate and individual registration is

\footnotetext{
${ }^{41}$ The WTO Agreement, enacted the Geographical Indications of Goods (Registration and Protection) Act, 1999 has come into force with effect from 15 September 2003. GIs have been defined under Article 22(1)
} 
granted in the names of actual users for geographical indication.

Benefits of registration of geographical indications: It confers legal protection to Geographical Indications in India, Prevents unauthorized use of a Registered Geographical Indication by others, It provides legal protection to Indian Geographical Indications which in turn boost exports. It promotes economic prosperity of producers of goods produced in a geographical territory. Some of the examples of the Indian GI are Alphanso Mango, Darjeeling Tea, Nagpur Orange, and Kolhapuri Chappal. The registration of a trademark which uses a geographical indication in a way that misleads the public as to the true place of origin must be refused or invalidated ex officio if the legislation so permits or at the request of an interested party (Article 22.3). ${ }^{42}$

Article 23 provides that interested parties must have the legal means to prevent the use of a geographical indication identifying wines for wines not originating in the place indicated by the geographical indication. This applies even where the public is not being misled, there is no unfair competition and the true origin of the good is indicated or the geographical indication is accompanied be expressions such as "kind", "type", "style", "imitation" or the like. Similar protection must be given to geographical indications identifying spirits when used on spirits. Protection against registration of a trademark must be provided accordingly.

Article 24 contains a number of exceptions to the protection of geographical indications. ${ }^{43}$ These exceptions are of particular relevance in respect of the additional protection for geographical indications for wines and spirits. ${ }^{44}$ For example, Members are not obliged to bring a geographical indication under protection, where it has become a generic term for describing the product in question. Measures to implement these provisions shall not prejudice prior trademark rights that have been acquired in good faith. Under certain circumstances, continued use of a geographical indication for wines or spirits may be allowed on a scale and nature as before. Members availing themselves of the use of these exceptions

\footnotetext{
42 The TRIPS Agreement, which came into effect on 1 January 1995 , is to date the most comprehensive multilateral agreement on intellectual property.

43 Available at-http://www.wto.org/english/tratop_e/trip

44 Available at-http://www.gnlu.ac.in/bc/Geographical\%20
}

must be willing to enter into negotiations about their continued application to individual geographical indications. The exceptions cannot be used to diminish the protection of geographical indications that existed prior to the entry into force of the TRIPS Agreement. The TRIPS Council shall keep under review the application of the provisions on the protection of geographical indication Trade mark is necessary for any product of IPR sector and the registration is most required for protection of the product. India has declared certain countries as convention countries, which afford to citizens of India similar privileges as granted to its own citizens. A person or company from a convention country, May within six months of making an application in the home country, apply for registration of the trademark in India. If such a trademark is accepted for registration, such foreign national will be deemed to have registered his or her trademark in India, from the same date on which he or she made application in the home country. Where the applications have been made for the registration of trademark in two or more convention countries, the period of six months would be reckoned from the date on which the earlier or earliest of those applications was made. Although the recovery of damages for infringement of a trademark is possible only if the infringement takes place after the date of filing application for registration with the concerned trademark office in India, yet the deemed seniority in making application in home country may entitle the applicant to initiate an action in India for injunction, delivery of impugned labels and so on.

The registration of a trade mark confers upon the owner the exclusive right to the use of the registered trade mark and indicates so by using the symbol (R) in relation to the goods or services in respect of which the mark is registered and seek the relief of infringement in appropriate courts in the country. The exclusive right is however subject to any conditions entered on the register such as limitation of area of use etc. Also, where two or more persons have registered identical or nearly similar mark due to special circumstances such exclusive right does not operate against each other.

The Indian government has taken several initiatives to create a conducive environment for the protection of intellectual property rights of innovators and creators by bringing about changes at legislative and policy 
level. ${ }^{45}$ Specific focus has been placed on improved service delivery by upgrading infrastructure, building capacity and using state-of-the-art technology in the functioning of intellectual property offices in the country. This measure has resulted in sweeping changes in IP administration within the country. ${ }^{46}$

The IPR framework in India is stable and well established from a legal, judicial and administrative point of view and is fully compliant with the Agreement on Trade-Related Aspects of Intellectual Property Rights. ${ }^{47}$ India is committed to wide range of international treaties and conventions relating to intellectual property rights. Wide range of awareness programmes are being conducted by the Government During the last few years, Indian IP offices have undergone major improvements in terms of up gradation of IP legislation, infrastructure facilities, human resources, the processing of IP applications, computerization, databases, quality services to stakeholders, transparency in functioning and free access to IP-data through a dynamic website. ${ }^{48}$

State of the art, integrated and IT- enabled office buildings have been created during the last few years in New Delhi, Kolkata, Chennai and Mumbai and Ahmadabad, housing central wings for Patents and Designs and Trademarks and Geographical Indications. The Patent Office is headquartered at Kolkata with branches at New Delhi, Chennai and Mumbai. The Trade Mark Registry, headquartered at Mumbai has branches in Ahmadabad, Chennai, New Delhi and Kolkata. The Design Office is located in Kolkata and the GI Registry is at Chennai. Separate facilities house the ISA/IPEA in New Delhi and additionally, there is an Intellectual Property Office Archives is at Ahmadabad. Simplified procedure for filing, E-filing facilities and incentives for SMEs are some of the other initiatives in the area of intellectual property rights in India. ${ }^{49}$

India is a member of the World Trade Organization and committed to the Agreement on Trade Related Aspects of Intellectual Property and member of World Intellectual Property Organization, a body responsible

\footnotetext{
${ }^{45}$ Available at- http://www.makeinindia.com/policy/intellectualproperty-facts

${ }^{46}$ ibid

47 ibid

${ }^{48}$ Available at- http://www.makeinindia.com/policy/intellectualproperty-facts

${ }^{49}$ ibid
}

for the promotion of protection of intellectual property rights throughout the world. India is also a member of the following important WIPOadministered International Treaties and Conventions relating to IPRs such as, Budapest Treaty on the International Recognition of the Deposit of Microorganisms for the Purposes of Patent Procedure, Paris Convention for the Protection of Industrial Property, Convention Establishing the World Intellectual Property Organization, Berne Convention for the Protection of Literary and Artistic Works, Patent Cooperation Treaty, Protocol Relating to the Madrid Agreement Concerning the International Registration of Marks- Madrid Protocol, Washington Treaty on Intellectual Property in respect of Integrated Circuits, Nairobi Treaty on the Protection of the Olympic Symbol and Convention for the Protection of Producers of Phonograms Against Unauthorized Duplication of Their Phonograms. ${ }^{50}$

India has taken strong steps in strengthening the patent system in the country. The Government aims at establishing a patent regime that is conducive to technological advances and is in line with its global commitments. Patent application filing at Indian Patent Office has been increasing consistently over the year which demonstrates the confidence of the global industry in the Indian patent ecosystem. Filing and processing of patent applications viz., examination, grant and post-grant proceedings are carried out at all the four Patent Office locations independently through a virtual network system which links all four Patent Offices; however, there is only one virtual Patent Office for the purpose of grant of patents. A patent is granted for a uniform period of 20 years from the filing date of the patent application for inventions in all fields of technology and it is a territorial right. The Indian Patent Office has been recognized as an International Searching Authority and an International Preliminary Examining Authority (ISA/IPEA) by World Intellectual Property Organization in October, 2007 under the Patent Cooperation Treaty, and has operationalised the status since 15th October, 2013, thus joining an elite group of 17 countries. 51

The Patent Office has a strong pool of experts for processing of patent applications. At present it has strength of 192 Examiners and 89 Supervising

\footnotetext{
${ }^{50}$ ibid

${ }^{51}$ Available at- http://www.makeinindia.com/policy/intellectualproperty-facts
} 
Officers. Among them, 42 have Doctorate degree, 75 are Post-Graduates in different branches of science, 25 have Post-Graduate degree in Engineering and 139 have Degree in Engineering/ Technology. For Patents, complete stock and flow information is available on the website. Every design to be registrable must pass the universal test of novelty. A registered design is valid for 10 years and can be further extended by another 5 years. A design cannot be registered if it is not new or original or has been disclosed to the public in India or anywhere in the world by publication. ${ }^{52}$

Several measures have been taken to ensure continuous and unending improvement of the Indian IP ecosystem in the country. To this effect, Department of Industrial Policy and Planning (DIPP), Ministry of Commerce \& Industry, Government of India, has formulated a multipronged strategy to develop an Intellectual Property regime in the country to promote creativity and to develop the culture of respect for innovations and creativity.

During the year, the Intellectual Property Office has been radically transformed through numerous initiatives that have contributed tremendously to easing of access to the IP system, efficiency in processing of IP applications, uniformity and consistency in the examination of applications, transparency and dissemination of IP information, bilateral cooperation at the international level, and raising the awareness level of the public. ${ }^{54}$

Several measures have been taken to create a strong and vibrant IP regime in India. These are: firstly: Modernization of administration such as Human Resources, Ease of access, online e-filing facilities. Comprehensive payment gateway and $10 \%$ rebate on online filing. Secondly: Transparency and dissemination of information. Thirdly: Fee Concession for MSME. Fourthly: Madrid Protocol. Fifthly: International Search Authority and

\footnotetext{
${ }^{52}$ ibid

53 Available at-

http://pib.nic.in/newsite/PrintRelease.aspx?relid=123202

${ }^{54}$ Press Information Bureau Government of India Ministry of Commerce \& Industry Intellectual Property Initiatives to Drive "Make in India", 13-July-2015 13:16 IST, retrieved on 13-062016.
}

International Preliminary Examining Authority. Sixthly: IPR Awareness Programmes such as IP Training, Awareness and Outreach Activities, National and international symposia / seminar / workshops on IP are organized for potential IP users, e-learning resources and Kids Nook etc.

\section{CONCLUISION-}

An intellectual property right for making in India into a new global scenario now becomes more valuable and vulnerable all over the world. since consumers and producer are sure to consumption of property genuinely and producer are sure to protect their product that nobody should copy or take brand of that product but due to some misuse of IPR other inventor are copying their product for self reliance. Though there are several organization such as WTO, GATT, WHIPO, TRIPS agreement are present for the protection of IPR but these are not sufficient for making India into a new techno society in this global world. Now it becomes challengeable to the consumers and inventors such as copy right of performing art, pharmaceutical products, recently yoga, DVD riders, agricultural product, geographical induction etc. For protecting the various issues in IPR regimes, there should strong provisions through Government in concerning countries and law should be separate for this provision and jurisdiction should be separate in different countries for that nobody either inside or outside of country will try it copy or hacking such type of valuable IP product. Now Parallel imports in patented and brand-name drugs arise for a variety of factors associated with price differences across markets: price discrimination by manufacturers, vertical price setting within distribution systems, and differential systems of price controls. As may be expected, PI have complex effects on markets in theory. So that a presumption in favor of restraining parallel trade could be supported. All the new invention and technology should protect from copy right because for making India into a new technology creates globalization. 